\title{
The Role of the Media in the Process of Shaping the Skills and Attitudes of Lower Secondary School Students
}

\section{KEYWORDS}

school, student, abilities, media, process

\begin{abstract}
Media play an important role in social and personal life. They affect opinion forming, promote trends and shape skills and attitudes. Their impact is enormous. Media can have both positive and negative influence, as they are addressed to adults and young people, whose opinions and characters have not yet crystallised. Thus the question about the extent to which the media shape abilities pertaining to the recognition of individual educational needs and learning, which is "(...) the foundation for success at school, in continuing education and in professional life." Results of research conducted among lower secondary school students provide answers to these questions.
\end{abstract}

\section{Introduction}

Despite the existence of various types of media, including the dynamic development of the Internet, television continues to be the most popular means of communication. "Over the decades, television has conquered Earth and its inhabitants, being the most successful invasion in history."

The expansion of television and its impact on humans is reflected in the following passage:

„Eric Mc Luhan, the son of a great media visionary, claims that in contemporary culture the content and information contained in television broadcasts is equivalent to the knowledge transmitted by shamans in tribal societies."

1 Z. Bauman, Społeczeństwo w stanie oblężenia, transl. J. Margański, Wydawnictwo Sic!, Warsaw 2006, p. 184

2 T. Goban-Klas, Cywilizacja medialna. Geneza, ewolucja, eksplozja. Wydawnictwa Szkolne i Pedagogiczne, Warsaw 2005, p. 43 
Digital TV offers a wide variety of thematic channels, TV programs are watched on computer screens, and the possibility to record them allows playback in a convenient time for the viewer. "Television is changing. These changes are related to the convergence process, the stronger connection between television and the Internet and other (mobile) media." ${ }^{3}$

The image of the world created by television is often adopted by viewers as their own. "The manner in which television presents the world becomes a model for presenting the world in general." ${ }^{4}$ Behavioural trends promoted by television, the interpretation of events are accepted without a deeper reflection by adults, but also by children and adolescents who do not yet have a well-developed moral backbone, i.e. they do not distinguish good from evil.

"We should bear in mind that TV shows perform different functions for broadcasters and advertisers, and different for the viewers. In the case of viewers they are a source of entertainment, pleasure and knowledge. Advertisers consider television programs as a "bait" to encourage certain categories of viewers to watch television and advertising spots. Whereas broadcasters focus on costs, and popularity and profits generated by the programs become a primary concern." ${ }^{5}$

Therefore, the economic result is very important and it may have a serious impact on the selection of programs and the content they convey. "Economics has the greatest impact on the program offer of commercial TV stations, but it also affects public television. Viewers want specific television products and that is what they get."

Bearing that in mind, there is a rising concern about the quality of the educational function of television, and its influence on shaping the skills and attitudes of lower secondary school students.

\section{Presentation of research results}

The aim of the research was to get acquainted with the opinion of lower secondary school students about the role of television in shaping selected skills defined in the Regulation of the Minister of National Education of 27 August 2012 on the

\footnotetext{
${ }^{3}$ H. Jenkins, Kultura konwergencji. Zderzenie starych i nowych mediów, transl. M. Bernatowicz, M. Filiciak, Wydawnictwo Akademickie i Profesjonalne, Warsaw 2007, p. 235

${ }^{4}$ N. Postman, Zabawić się na śmierć, Dyskurs publiczny w epoce show-businessu, transl. L. Niedzielski, Warsaw, Wydawnictwo Literackie MUZA SA, Warsaw 2002, p. 137

${ }^{5} \mathrm{~K}$. Arcimowicz, Dyskursy o płci i rodzinie w Polskich telesagach, Wydawnictwo Akademickie ŻAK, Warsaw, 2013, p. 103

${ }^{6}$ K. Arcimowicz, Dyskursy o ptci i rodzinie w Polskich telesagach ..., op. cit., p. 104
} 
core curriculum of pre-school education and general education in particular types of schools (Journal of Laws, 977) i.e.:

"(...) 6) the ability to search, select and critically analyse information;

(7) the ability to recognize one's own educational needs and learning;

8) teamwork skills;"”

In addition, the study was also intended to gain knowledge about the acceptance of film characters as role models by lower secondary school students.

The study was carried out from October 3 - 16, 2015 in the School Complex No. 112 in Warsaw (Praga-Północ District), which consists of Lower Secondary School No. 32 and Primary School with Integration Classes No. 354.

The study comprised students of two classes of Lower Secondary School No. 32 (class IIa and IIc) - a total of 60 students, including 25 girls and 35 boys. The surveyed group consisted of a total of 31 students from two-parent families, including 13 girls and 18 boys, and 29 students from single-parent families, including 12 girls and 17 boys.

For the purpose of the study, a survey questionnaire was developed, including open and closed questions.

Out of a total of 60 students, 55 students - including 24 girls and 31 boys confirmed their interest in watching television; 5 students - including 1 girl and 4 boys - did not confirm their interest in watching television.

In the group of respondents who confirmed their interest in watching television, the results of the study based on family structure are as follows: 29 students, including 13 girls and 16 boys, were from two-parent families, whereas 26 students, including 11 girls and 15 boys, were from single-parent families.

In the group of respondents who did not confirm their interest in watching television, the results of the study based on family structure are as follows: 2 boys were from two-parent families, and 3 students, including 1 girl and 2, boys were from single-parent families.

The results show that the majority of students are interested in watching TV programs, which also indicates how they spend their free time. The results also show that in the surveyed group boys showed more interest in watching TV than girls. A small group - only five students - declared a lack of interest in watching

7 Section 4 of Appendix 4 Core curriculum of general education for lower secondary schools and upper secondary schools, whose completion allows to obtain a maturity certificate upon passing the matriculation examination to the Regulation of the Minister of National Education of 27 August 2012 on the core curriculum of pre-school education and general education in particular types of schools (Journal of Laws, item 977) p. 73 
TV programs. This may be caused by, for example, a greater interest in computer games.

When asked about the frequency of watching television, 55 respondents who declared they watch television gave the following answers:

- 5 hours and more -5 students, including 2 girls and 5 boys

- every day from 3 to 5 hours -8 students, including 4 girls and 4 boys,

- every day from 1 to 3 hours - 38 students, including 17 girls and 21 boys,

- 6 students, including 2 girls and 2 boys, did not provide an answer.

Of the 24 girls who declared watching television, the responses - based on family structure - were as follows:

- 5 hours and more -2 girls from two-parent families,

- every day from 3 to 5 hours - 4 girls, including 1 from a two-parent family and 3 from single-parent families,

- every day from 1 to 3 hours - 17 girls, including 10 from two-parent families and 7 from single-parent families,

- 2 students did not provide an answer

The frequency of watching television declared by girls based on family structure.

The surveyed boys ( 35 students) gave the following answers, based on family structure:

- 5 hours and more -3 boys, including 1 from a two-parent family and 2 from single-parent families,

- every day from 3 to 5 hours - 4 boys, including 2 from two-parent families and 2 from single-parent families,

- every day from 1 to 3 hours -21 boys, including 9 from two-parent families and 12 from single-parent families,

- 3 students did not provide an answer, including 1 from a two-parent family and 2 from single-parent families.

The group of students who watched television every day from 1 to 3 hours was dominant among the respondents, whereas boys constituted a bigger group - 21 students, including 9 from two-parent families and 12 from single-parent families. The small difference between the group of boys from two-parent families and boys from single-parent families suggests that watching television is the dominant form 
of spending their free time for boys in both types of families. The study also reveals that both types of families are not particularly concerned about diversifying the form in which the boys spend their free time.

An opposite trend was observed among girls who declared watching TV for 1 to 3 hours: among the 17 students -10 were from two-parent families and 7 from single-parent families. Although the number of respondents in both groups is similar, it is disturbing that the larger group consists of girls from two-parent families. This may indicate little concern for tightening family relationships, family atmosphere or even little parental interest in their child.

The group of eight students who declared watching TV every day from 3 to 5 hours is also worth mentioning. This group consisted of 4 girls and 4 boys, whereas 3 girls were from single-parent families and 1 from a two-parent family. This may be a disturbing signal that the parent has no interest in the child or no time for the child. In the group of boys there was a balance -2 boys came from two-parent families and 2 from single-parent families. It may be assumed that the parents' approach to raising boys is similar in both types of families. They allow for greater freedom and self-reliance in organizing their free time.

The smallest group consisted of students who declared watching TV every day for 5 hours or more. This included 2 girls and 3 boys. The small difference in the number of respondents in both groups based on gender signals an important problem concerning the manner in which students of the surveyed classes spend their free time, both in two-parent families and single-parent families. The study reveals the parents' lack of interest in their children, but also the monotony and repetitiveness of the students' lives.

When asked about the reasons for watching TV, the respondents gave the following answers:

- I expand the knowledge I gain at school - 6 answers, including 3 girls and 3 boys,

- I develop my interests - 20 answers, including 9 girls and 11 boys,

- I learn patterns of behaviour that may be an example for me - 5 answers, including 2 girls and 3 boys,

- to relax - 23 answers, 12 girls and 11 boys,

- from boredom - 32 answers, including 14 girls and 18 boys,

Several answers could be indicated to the above questions. 
Chart 1. Reasons for watching television - based on gender (several responses could be indicated)

Own study

- When asked about the reasons for watching television, the girls responded as follows:

- I expand the knowledge I gain at school - 3 girls, including 2 from two-parent families and 1 from a single-parent family,

- I develop my interests -9 girls, including 5 from two-parent families and 4 from single-parent families,

- I learn patterns of behaviour that may be an example for me - 2 girls, including 1 from a two-parent family and 1 from a single-parent family,

- to relax - 12 girls, including 7 from two-parent families and 5 from single-parent families,

- from boredom - 14 girls, including 7 from two-parent families and 7 from single-parent families,

- other reasons - not indicated

- lack of response - 20 girls, including 9 from two-parent families and 11 from single-parent families,

Chart 2. Reasons for watching television by girls - based on family structure

Own study

When asked about the reasons for watching television, the boys responded as follows:

- I expand the knowledge I gain at school - 3 boys, including 1 from a two-parent family and 2 from single-parent families,

- I develop my interests - 11 boys, including 4 from two-parent families and 7 from single-parent families,

- I learn patterns of behaviour that may be an example for me - 3 boys from single-parent families,

- to relax - 11 boys, including 5 from two-parent families and 6 from single-parent families,

- from boredom - 18 boys, including 10 from two-parent families and 8 from single-parent families,

Chart 3. Reasons for watching television by boys - based on family structure

Own study

When asked about the most frequently viewed programs, the respondents gave the following answers:

- films - 44 answers, 19 girls and 25 boys,

- gameshows/ competitions - 7 answers, including 4 girls and 3 boys,

- educational programs - 9 answers, including 2 girls and 7 boys,

- nature programs - 16 answers, 7 girls and 9 boys,

- travel programs - 10 answers, including 4 girls and 6 boys,

- news/ political discussions - 5 answers, including 1 girl and 4 boys.

- other -0 answers 
Chart 4 . The most frequently viewed programs - based on gender

(several responses could be indicated)

Own study

When asked about the most frequently viewed programs, girls gave the following answers (based on family structure):

- films - 19 answers, 9 girls from two-parent families and 10 girls from single-parent families,

- gameshows/ competitions - 4 answers, 1 girl from a two-parent family and 3 girls from single-parent families,

- educational programs - 2 answers, 2 girls from two-parent families

- nature programs - 7 answers, 2 girls from two-parent families and 5 girls from single-parent families,

- travel programs - 4 answers, 1 girl from a two-parent family and 2 girls from single-parent families,

- news/ political discussions - 1 girl from a couple family.

- other -0 answers.

Chart 5. Programs most frequently watched by girls - based on family structure (several responses could be indicated):

Own study

When asked about the most frequently viewed programs, boys gave the following answers (based on family structure):

- films - 25 answers, including 2 boys from two-parent families and 23 boys from single-parent families,

- gameshows/ competitions -3 answers, 3 boys from single-parent families,

- educational programs - 7 answers, 1 boy from a two-parent family and 6 boys from single-parent families,

- nature programs - 9 answers, including 9 boys from single-parent families,

- travel programs -6 answers, including 6 boys from single-parent families,

- news/ political discussions - 4, including 1 boy from a two-parent family and 3 boys from single-parent families.

- other -0 answers.

Chart 6. Programs most frequently watched by boys - based on family structure (several responses could be indicated)

Own study

When asked about the types of films watched by the respondents, the following answers were provided (by gender) (several responses could be indicated):

- $\quad$ series (e.g. Brazilian soap operas) - 14 answers, including 5 girls and 9 boys,

- crime films - 20 answers, including 7 girls and 13 boys

- adventure films - 17 answers, including 8 girls and 9 boys,

- costume films - 0 answers, 
- comedies - 32 answers, including 13 girls and 19 boys,

- science fiction film - 11 answers, including 5 girls and 6 boys,

- other -0 answers.

Chart 7. Types of films most frequently watched by the respondents - by gender (several responses could be indicated)

Own study

When asked about the types of films they watched most frequently, girls responded as follows:

- series (e.g. Brazilian soap operas) - 5 answers, including 2 girls from two-parent families and 3 girls from single-parent families,

- crime films - 7 answers, including 2 girls from two-parent families and 5 girls from single-parent families,

- adventure films -8 answers, including 4 girls from two-parent families and 4 girls from single-parent families,

- costume films - 0 answers,

- comedies - 13 answers, including 4 girls from two-parent families and 9 girls from single-parent families,

- science fiction films - 5 answers, including 2 girls from two-parent families and 3 girls from single-parent families,

- other -0 answers.

Chart 8 . Types of films most frequently watched by girls - by family structure (several responses could be indicated)

Own study

When asked about the types of films they watched most frequently, boys responded as follows:

- series (e.g. Brazilian soap operas) - 5 answers, including 2 girls from two-parent families and 3 girls from single-parent families,

- crime films - 7 answers, including 2 girls from two-parent families and 5 girls from single-parent families,

- adventure films - 8 answers, including 4 girls from two-parent families and 4 girls from single-parent families,

- costume films - 0 answers,

- comedies - 13 answers, including 4 girls from two-parent families and 9 girls from single-parent families,

- science fiction film - 5 answers, including 2 girls from two-parent families and 3 girls from single-parent families,

- other -0 answers.

Chart 9. Types of films most frequently watched by boys - by family structure (several responses could be indicated)

Own study

According to the study, out of a total of 60 students, 27 students, including 11 girls and 16 boys, declared that film characters were role models for them, 32 respondents, including 13 girls and 19 boys, were of an opposite opinion. One girl claimed that film characters were not always a role model for her. 
Chart 10. The students' opinion about whether film characters are role models for them - based on gender (several answers could be indicated)

Own study

The study revealed that out of the total of 25 girls, from the group of 11 girls who confirmed accepting the behaviour of film characters as a role model, 6 girls came from two-parent families and 5 from single-parent families. At the same time, of the 13 respondents who were of the opposite opinion, 9 came from two-parent families and 4 from single-parent families. One respondent, who declared that she did not always accept the behaviour of film characters as a role model, came from a two-parent family.

Chart 11. The opinion of the surveyed girls on whether film characters are role models for them based on family structure (several answers could be indicated)

Own study

The study revealed that out of the total of 35 boys, from the group of 16 boys who confirmed accepting the behaviour of film characters as a role model, 7 boys came from two-parent families and 9 from single-parent families. At the same time, of the 19 respondents who were of the opposite opinion, 11 came from two-parent families and 8 from single-parent families.

Chart 12. The opinion of the surveyed boys on whether film characters are role models for them based on family structure (several answers could be indicated)

Own study

During the study, the respondents gave examples of how they were influenced by film characters. Of the total of 60 respondents, 17 students, including 7 girls and 10 boys, answered the question. 43 students, including 18 girls and 25 boys, did not provide an answer.

Here are the answers (based on gender):

1. I plan to behave like that in adult life -8 students, including 5 girls and 3 boys,

2. I plan to perform the same profession as the film character -6 students, including 1 girl and 5 boys,

3. I plan to be an actor in adult life -3 students, including 1 girl and 2 boys.

4. other -0 .

Chart 13. Examples - provided by respondents - of the impact of film characters (based on gender) (several answers could be given)

Own study

The surveyed girls gave the following examples of the impact of film characters (based on family structure):

5. I plan to behave like that in adult life -5 girls, including 2 girls from two-parent families and 3 girls from single-parent families, 
6. I plan to perform the same profession as the film character - 1 girl from a two-parent family,

7. I plan to be an actor in adult life - 1 girl from a two-parent family,

8. Other -0

9. No answer - 18 girls, including 7 girls from two-parent families and 11 girls from single-parent families,

Chart 14. Examples - provided by the surveyed girls - of the impact of film characters (based on gender) (several answers could be given)

Own study

The surveyed boys gave the following examples of the impact of film characters (based on family structure):

10. I plan to behave like that in adult life -3 boys, including 1 boy from a two-parent family and 2 boys from single-parent families,

11. I plan to perform the same profession as the film character -5 boys, including 2 boys from two-parent families and 3 boys from single-parent families,

12. I plan to be an actor in adult life -2 boys from single-parent families,

13. Other -0

14. No answer - 25 boys, including 11 boys from two-parent families and 14 boys from single-parent families

Chart 15. Examples - provided by the surveyed boys - of the impact of film characters (based on gender) (several answers could be given)

Own study

When asked about the skills taught by television, the respondents answered as follows:

- teamwork skills - 18 answers, including 4 girls and 14 boys,

- the ability to recognize one's own educational needs and learning - 18 answers, including 9 girls and 9 boys,

- the ability to search, select and critically analyse information - 18 answers, including 7 girls and 11 boys.

- other -0 .

Chart 16. Skills taught by television - according to the respondents (based on gender) (several answers could be given)

Own study

Based on family structure, the surveyed girls provided the following answers to the question about skills taught by television:

- teamwork skills - 4 answers, including 4 girls from two-parent families

- the ability to recognize one's own educational needs and learning - 9 answers, including 7 girls from two-parent families and 2 girls from single-parent families,

- the ability to search, select and critically analyse information -7 answers, including 6 girls from two-parent families and 1 girl from a single-parent family.

- other -0 
Chart 17. Skills taught by television - according to the surveyed girls (based on family structure) (several answers could be given)

Own study

Based on family structure, the surveyed boys provided the following answers to the question about skills taught by television:

- teamwork skills - 14 answers, including 9 boys from two-parent families and 5 boys from single-parent families,

- the ability to recognize one's own educational needs and learning - 9 answers, including 5 girls from two-parent families and 4 girls from single-parent families,

- the ability to search, select and critically analyse information - 11 answers, including 5 boys from two-parent families and 6 boys from single-parent families.

- other -0

Chart 18 . Skills taught by television - according to the surveyed boys (based on family structure) (several answers could be given)

Own study

When asked whether television helps respondents in determining further educational plans, 23 students gave a positive answer, including 8 girls and 15 boys, and 37 students, including 17 girls and 20 boys, gave a negative response.

Chart 19. Opinion of the respondents on whether television helps them in determining further educational plans (based on gender) (several answers could be indicated)

Own study

Based on family structure, among the 25 surveyed students, 8 girls, including 4 from two-parent families and 4 from single-parent families, declared that television helps them determine further educational plans, 17 were of an opposite opinion, including 9 from two-parent families and 8 from single-parent families.

Chart 20. Opinion of the surveyed girls on whether television helps them in determining further educational plans (based on family structure) (several answers could be indicated)

Own study

Based on family structure, among the 35 surveyed students, 15 boys, including 9 from two-parent families and 6 from single-parent families, declared that television helps them determine further educational plans, 20 boys were of an opposite opinion, including 9 from two-parent families and 11 from single-parent families.

Chart 21. Opinion of the surveyed boys on whether television helps them in determining further educational plans (based on family structure) (several answers could be indicated)

Own study 


\section{Summary}

According to the carried out research, students from class IIa and IIc of the Lower Secondary School No 112 in Warsaw (Praga-Północ District) are of the opinion that television teaches them the skills defined in the Regulation of the Minister of National Education of 27 August 2012 on the core curriculum of pre-school education and general education in particular types of schools (Journal of Laws, item 977), i.e.: teamwork, recognition of one's own educational needs and learning, and the ability to search, select and critically analyse information. It is worth noting that:

"From kindergarten to university, education law imposes the obligation to shape skills and attitudes, apart from conferring knowledge."

"The learning objectives are formulated in the language of learning outcomes, described as general requirements, and the content of teaching and the expected students' abilities are defined as specific requirements.(...) In the end, the implementation of these objectives should prepare students to be creative and for innovative, creative lifelong learning."'

The changing world, the unpredictability of the future necessitates the search for new methods of conducting the process of teaching and educating students. "Finding ways to teach and educate for the future makes it necessary to change the way we build our curricula, including, inter alia, shaping skills/competencies." ${ }^{10}$

Among the students who found that television taught them teamwork skills, boys were the dominant group (14), only 4 girls indicated this answer. The ability to identify one's own educational needs and learning was indicated by 9 girls and 9 boys. The ability to search, select and critically analyse information was indicated by 7 girls and 11 boys. It is worth noting that the group of respondents who declared they watch television (Chart 2) was also dominated by boys (31), while among the surveyed girls -24 declared their interest in watching television.

It is noteworthy that when asked whether television helps students in determining further educational plans, the majority, 37 surveyed students, including 17 girls and 20 boys, gave a negative answer; 28 students, including 8 girls and 15 boys, confirmed that, in their opinion, television helps students determine further educa-

${ }^{8}$ I. Kust, Pedagogika dialogu. Wokół pedagogiki Janusza Korczaka, [in:] D. Jankowska, (ed.) Kreatywność w pedagogice Janusza Korczaka i edukacji dla rynku pracy w XXI wieku, Wydawnictwo Akademii Pedagogiki Specjalnej, Warsaw 2014, p. 299

9 I. Kust, Pedagogika dialogu. Wokół pedagogiki Janusza Korczaka ..., op. cit., p. 299

${ }^{10}$ J. Michalak-Dawidziuk, Kształtowanie kompetencji społecznych jako przygotowanie do funkcjonowania w społeczeństwie transgresyjnym, [in:] A. Kryniecka (ed.) Dzisiejsze znaczenie ideałów, Kresowa Agencja Wydawnicza, Białystok 2015, p. 58 
tional plans. Hence the importance of the role of the school, which should support lower secondary school students in this difficult and responsible task. "Shaping skills, planning one's career path, professional career are another important aspect in the rapidly changing job market." ${ }^{11}$

The study shows that television teaches specific skills, however, in the opinion of a large part of the surveyed students it does not help in developing further educational plans.

At the same time, the study also answered the question whether lower secondary school students accept film characters as role models. The results showed that most of the respondents - 32 students - did not confirm accepting film characters as role models. This group was dominated by boys (19 students), the group of girls consisted of 13 students.

However, 27 students (including 11 girls and 16 boys) confirmed this fact.

It should be noted that among the 13 surveyed girls who declared that they did not accept the behaviours of film characters as role models - 9 came from two-parent families, and only 4 from single-parent families.

A similar tendency was observed in the group of surveyed boys. Of the 19 respondents who declared they did not follow the example of film characters, 11 came from two-parent families, while only 8 from single-parent families.

At the same time, in the group of respondents who confirmed accepting the behaviour of film characters as role models, different tendencies were observed: in the group of girls - 6 girls came from two-parent families and 5 from single-parent families, whereas in the group of boys -7 boys came from two-parent families and 9 from single-parent families.

Taking into consideration the above answers, it is interesting to take a look at the preference for film genres shown by lower secondary school students.

The results of research show that comedies are the most preferred film genre, with boys (19 students) dominating the group, whereas 13 girls declared their interest in comedies. The second largest group of responses included crime films. In this case, boys were also more numerous (13 students), while the girls constituted a group of 7 students. 17 responses concerned adventure films. In the case of this particular film genre, there were no significant differences in the number of indications - 9 boys and 8 girls. Next - 14 responses - students indicated series (e.g. Brazilian soap operas) -5 girls and 9 boys. Minor variations occurred with respect to science fiction films - 11 responses, including 5 girls and 6 boys.

11 I. Kust, Wyzwania dla edukacji permanentnej wobec zmieniającego się świata, [in:] I. Janicka, M. Znajmiecka - Sikora (ed.) Rodzina i kariera. Równoważenie, czy konflikt? Wydawnictwo Uniwersytetu Łódzkiego, Łódź 2014, p. 315 
On the other hand, respondents did not indicate costume films.

The said research results raised a lot of concern with respect to the influence of film characters on the respondents. Out of the total of 60 students - 27 students, including 11 girls (6 from two-parent families and 5 from single-parent families) and 16 boys ( 7 from two-parent families and 9 from single-parent families), declared they modelled their behaviour on film characters.

The results presented in the above section confirm, to a large extent, the preferences of young people presented in J. Bednarek's article "Multimedia in training and education activities." 12

"Analysing the results of the studies on the preferences of young people with respect to television programs ${ }^{13}$, it may be said that television mainly fulfils their interest in films (38\%).

- comedies, including series (71.23\%);

- action films (55\%);

- horror films (41.09\%);

- dramas (46.43\%);

- documentaries (24.65\%);

- fantasy films (10.95\%).

Historical films occupy the lowest position as far as the preferences of young people are concerned (1.36\%)."14

It is also worth recalling other results of the study "Lower secondary school students were asked a question (...) about their favourite TV scenes. The responses indicate that most $(80 \%)$ of the respondents like to watch action scenes, i.e. scenes that build tension and provide strong experiences, such as street gangs fights, brutal scenes of murders, chase, shooting. As many as $66 \%$ of the respondents admitted that they watch television scenes presenting violence, cruelty, ruthlessness. The next group of responses included: humorous scenes (62\%), erotic scenes (58\%), scenes showing unusual events $(50 \%)$. These were followed by battles scenes $(32 \%)$." 15

The presented comparison of three different research results - despite the lack of uniformity of, for example, the questions addressed to respondents - shows

\footnotetext{
12 J. Bednarek, Multimedia w działalności szkoleniowo-wychowawczej, MON, Warsaw 2000, p. 69

${ }^{13}$ M. Krzyśko, Jakim odbiorca treści telewizyjnych jest młodzież [in:] Media a edukacja, III International Conference Poznań, 2000, pp. 132 -134

${ }^{14}$ J. Bednarek, Multimedia $w$ działalności szkoleniowo-wychowawczej ..., op. cit., p. 69

${ }^{15}$ A. Repko, Wplyw programów telewizyjnych na postawy i zachowania młodzieży gimnazjalnej [in] St. Juszczyk (ed.), Edukacja medialna w społeczeństwie informacyjnym, Wydawnictwo Adam Marszałek, Toruń 2003
} 
a clear tendency in their preferences for television programs. The most frequently watched programs / films / scenes - in the case of the first two studies - include crime (action) films / or action scenes, and in the case of the third study humorous scenes, which in the first two studies came second. In the case of research on the most frequently watched television scenes, action scenes were ranked first.

The lowest position - also in the first two studies - included a number of responses indicating costume / historical films. In the case of studies on television scenes, battle scenes.

It should be noted that the study was carried out in Praga-Północ district, which has a strong pathological environment. Therefore, the fact that a significant number of the surveyed lower secondary school students declared they are influenced by characters of crime films is particularly disturbing. Media, including television, are part of the everyday life of young people, who adopted this way of spending their free time from the environment in which they grew up, i.e. their family, peers. "It is noteworthy that Poles spend more and more time watching television (according to the Centre for Public Opinion Research (...) in 2010 it was 3 hours 42 minutes, whereas in 2005 - 26 minutes less." ${ }^{16}$ Undoubtedly, “(...) popular culture and its heroes are a source of meaning in everyday life for the young generation and give them a sense of community. The problem of evaluating this phenomenon is not important. There is no point in wondering whether it is good or bad. Such a view allows to avoid the destructive collision of arbitrary systems of concepts and values of all-knowing educators with the imagination of young people, who derive it mainly from popular culture"17

However, it is necessary to strengthen the role of the teacher, especially the teacher operating in a pathological environment. His/her awareness and involvement in the educational process can provide opportunities for the student to discover patterns that he or she does not encounter in the everyday life of the environment in which he or she lives.

The curriculum of lower secondary schools ${ }^{18}$ underlines the importance of media education in the process of education, including the development of skills and attitudes:

${ }^{16}$ K. Arcimowicz, Dyskursy o płci i rodzinie w polskich telesagach ...op. cit., p.101

17 Z. Melosik, Kultura popularna. Walka o znaczenia i pedagogika, [in] A. Gromkowska-Melosik, Z. Melosik (ed.) Kultura popularna: konteksty teoretyczne i społeczno-kulturowe, Oficyna Wydawnicza „Impuls”, Kraków 2010, p. 21

${ }_{18}$ Section 4 of Appendix 4 Core curriculum of general education for lower secondary schools and upper secondary schools, whose completion allows to obtain a maturity certificate upon passing the matriculation examination to the Regulation of the Minister of National Education of 27 August 2012 on the core curriculum of pre-school education and general education in particular types of schools ...., op. cit., p. 73 
"As the mass media play an increasingly important role in both social and personal life, every teacher should devote a lot of attention to media education, i.e. educating the students to a proper reception and use of the media." ${ }^{19}$

Without pointing to the need to build the authority of the teacher or act as a mentor in an environment of students from disadvantaged backgrounds, it is worth appealing to his or her emotional competence. According to Joanna Madalińska - Michalak "Sufficiently developed emotional competencies are necessary for those who perform work requiring patience, commitment, time and understanding of others." ${ }^{20}$ Continuing this thought, the scholar states, "The current need for a teacher who understands the direction of changes and participates in them means abandoning the role of a teacher limited to the classroom in order to position him/her in the cultural perspective. (...) In order to improve communication and relations between people, emotional competencies should be enhanced with the intercultural dimension, which would improve interaction between teachers and students." 21

Therefore, the teacher's awareness of the environment in which he/she works, their ability to observe, analyse, draw the right conclusions, inquisitiveness are the basis of the teacher's work in a socially neglected environment. Of course, these qualities should be a standard for any teacher in any environment, however, the teacher in question, having these qualities and sensibilities, can create a relationship with the student, which enables the actual realization of the educational process, including shaping the appropriate attitude of lower secondary school students to the available television offer.

Tomasz Szkudlarek, when determining the postulates for media education, wrote, among other things, “... the school should undoubtedly pay attention to the relationship between representation and simulation, or, in another dimension, between reality and the virtual world." ${ }^{22}$ Continuing this statement, he says "... an important aspect of media education should be the critical analysis of the relationship between group and individual values in the area of cultural conventions, as

\footnotetext{
${ }^{19}$ Section 4 of Appendix 4 Core curriculum of general education for lower secondary schools and upper secondary schools, whose completion allows to obtain a maturity certificate upon passing the matriculation examination to the Regulation of the Minister of National Education of 27 August 2012 on the core curriculum of pre-school education and general education in particular types of schools ..., op. cit., p. 73

${ }^{20}$ J. Madalińska-Michalak, R. Góralska, Kompetencje emocjonalne nauczyciela, Wolters Kluwer Polska SA, Warsaw 2012, p. 110

${ }_{21}$ J. Madalińska-Michalak, R. Góralska, Kompetencje emocjonalne nauczyciela ..., op. cit., p. 118

${ }_{22}$ T. Szkudlarek, Media. Szkic z filozofii i pedagogiki dystansu, Oficyna Wydawnicza „Impuls”, Kraków 2009, p. 135
} 
well as the relationship between them." In this context, he stresses the importance of education.

Wacław Strykowski, describing the tasks for media education, states: “... it is important to conduct media education, the main goal of which is to prepare students for an effective use of the media as a tool for intellectual activity and to prepare them for conscious and critical reception of media messages." ${ }^{23}$

At the same time, it is worth remembering that "... in the postmodern world, we tend to feel that information is frequently transmitted to induce specific social groups and individuals, to persuade them, sometimes even to enslave them in order to achieve the so-called higher goals that are to serve other people." ${ }^{24}$

In this context, the role of media education is very significant. The need to increase the awareness of the above mechanisms among students from a neglected environment, young people with undeveloped attitudes, is of particular importance.

"Every school operating in disadvantaged areas is unique and has its own history and problems which it has to face and its own development opportunities. ${ }^{25}$ This can be a message for every teacher, but it is of special importance in the context of the teacher working with students from pathological families, single-parent families.

"From the student's perspective, school is not just for education; it is also a place where they spend a lot of time. Practices related to teaching are included in the broader context of sociability, negotiation of hierarchy, formalization and standardization of the learning process." 26 Therefore, the relationship that the teacher creates with the student must be marked by the teacher's empathy and culture.

"Every individual is unique. Therefore, self-reflection and awareness of the role of education in human life are very important. Education is a way to achieve authentic, harmonious human development." ${ }^{27}$

${ }^{23}$ W. Strykowski, Kształcenie wspomagane mediami a edukacja medialna, Współczesna technologia informacyjna i edukacja medialna, [in] T. Lewowicki, B. Siemieniecki, (ed.) Multimedia Biblioteka Pedagogiczna Wydawnictwo Adam Marszałem, Toruń 2008, p. 37

${ }^{24}$ K. Wenta, Telewizja internetowa w edukacji, E. Musiał, I. Pulak (ed.) Człowiek Media Edukacja, Uniwersytet Pedagogiczny KEN in Kraków, Kraków 2011, p. 403

${ }^{25}$ J. Madalińska -Michalak, Skuteczne przywództwo w szkołach na obszarach zaniedbanych społecznie. Studium porównawcze, Wydawnictwo Uniwersytetu Łódzkiego, Łódź 2012, p. 152

${ }^{26}$ T. Szkudlarek, W szkole, [in] M. Filiciak, M. Danielewicz, M. Halawa, P. Mazurek, A. Nowotny, Młodzi i media. Nowe media a uczestnictwo w kulturze, Szkoła Wyższa Psychologii Społecznej, Warsaw 2010, p. 112

${ }^{27}$ J. Michalak-Dawidziuk, Lifelong Learning - potrzeba współczesnego rynku pracy czy całożyciowa autokreacja człowieka? Transgresje w edukacji, [in] I. Paszenda, R. Włodarczyk (ed.), Oficyna Wydawnicza „Impuls”, Kraków 2014, p. 222 


\section{References}

Arcimowicz K., Dyskursy o płci i rodzinie w polskich telesagach, Wydawnictwo Akademickie ŻAK, Warsaw, 2013

Bauman Z., Społeczeństwo w stanie oblężenia, transl. J. Margański, Wydawnictwo Sic!, Warsaw 2006

Bednarek J., Multimedia $w$ działalności szkoleniowo-wychowawczej, MON, Warsaw 2000, Goban-Klas T., Cywilizacja medialna. Geneza, ewolucja, eksplozja. Wydawnictwa Szkolne i Pedagogiczne, Warsaw 2005

Jenkins H., Kultura konwergencji. Zderzenie starych $i$ nowych mediów, transl. M. Bernatowicz, M. Filiciak, Wydawnictwo Akademickie i Profesjonalne, Warsaw 2007

Krzyśko M., Jakim odbiorca treści telewizyjnych jest młodzież [in:] Media a edukacja, III International Conference Poznań 2000

Kust I., Wyzwania dla edukacji permanentnej wobec zmieniającego się świata, [in] I. Janicka, M. Znajmiecka - Sikora (ed.) Rodzina i kariera. Równoważenie, czy konflikt? Wydawnictwo Uniwersytetu Łódzkiego, Łódź 2014,

Kust I., Pedagogika dialogu. Wokół pedagogiki Janusza Korczaka, [in] D. Jankowska, (ed.) Kreatywność w pedagogice Janusza Korczaka i edukacji dla rynku pracy w XXI wieku, Wydawnictwo Akademii Pedagogiki Specjalnej, Warsaw 2014

Madalińska-Michalak J., Skuteczne przywództwo w szkołach na obszarach zaniedbanych społecznie. Studium porównawcze, Wydawnictwo Uniwersytetu Łódzkiego, Łódź 2012, Madalińska-Michalak J., Góralska R., Kompetencje emocjonalne nauczyciela, Wolters Kluwer Polska SA, Warsaw 2012,

Michalak-Dawidziuk J., Kształtowanie kompetencji społecznych jako przygotowanie do funkcjonowania w społeczeństwie transgresyjnym, [in] A. Kryniecka (ed.) Dzisiejsze znaczenie ideałów, Kresowa Agencja Wydawnicza, Białystok 2015,

Michalak-Dawidziuk J., Lifelong Learning - potrzeba współczesnego rynku pracy czy całożyciowa autokreacja człowieka? Transgresje w edukacji, [in] I. Paszenda, R. Włodarczyk (ed.), Oficyna Wydawnicza „Impuls”, Kraków 2014, Melosik Z., Kultura popularna. Walka o znaczenia i pedagogika, [in] A. Gromkowska-Melosik.

Z. Melosik (ed.) Kultura popularna: konteksty teoretyczne i społeczno-kulturowe, Oficyna Wydawnicza „Impuls”, Kraków 2010,

Okońska-Walkowicz A., Plebańska M., Szaleniec H., O kompetencjach kluczowych, e-learningu i metodzie projektu, Wydawnictwa Szkolne i Pedagogiczne S.A., Warsaw 2009 Postman N., Zabawić się na śmierć, Dyskurs publiczny w epoce show-businessu, transl. L. Niedzielski, Warszawa, Wydawnictwo Literackie MUZA SA, Warsaw 2002

Repko A., Wpływ programów telewizyjnych na postawy i zachowania młodzieży gimnazjalnej [in] Juszczyk St. (ed.), Edukacja medialna $w$ społeczeństwie informacyjnym, Wydawnictwo Adam Marszałek, Toruń 2003,

Strykowski W., Kształcenie wspomagane mediami a edukacja medialna, Współczesna technologia informacyjna i edukacja medialna, [in] T. Lewowicki, B. Siemieniecki, (ed.) Multimedia Biblioteka Pedagogiczna Wydawnictwo Adam Marszałem, Toruń 2008.

Szkudlarek T., W szkole, [in] M. Filiciak, M. Danielewicz, M. Halawa, P. Mazurek, A. Nowotny, Młodzi i media. Nowe media a uczestnictwo w kulturze, Szkoła Wyższa Psychologii Społecznej, Warsaw 2010 
Szkudlarek T., Media. Szkic z filozofii i pedagogiki dystansu, Oficyna Wydawnicza „Impuls”, Kraków 2009

Wenta K., Telewizja internetowa w edukacji, [in] E. Musiał, I. Pulak (ed.) Człowiek Media Edukacja, Uniwersytet Pedagogiczny KEN w Krakowie, Kraków 2011,

\section{Legal acts}

Section 4 of Appendix 4 Core curriculum of general education for lower secondary schools and upper secondary schools, whose completion allows to obtain a maturity certificate upon passing the matriculation examination to the Regulation of the Minister of National Education of 27 August 2012 on the core curriculum of pre-school education and general education in particular types of schools (Journal of Laws, item 977) p. 73 